\title{
Flower Characteristics and the Yield of Jatropha (Jatropha curcas L.) Accessions
}

\author{
ANDI WIJAYA ${ }^{1 *}$, SUSANTIDIANA ${ }^{3}$, MUHAMAD UMAR HARUN ${ }^{1}$, HENY HAWALID ${ }^{2}$ \\ ${ }^{1}$ Faculty of Agriculture, Sriwijaya University, Indralaya Ogan Ilir, Indralaya 33692, Sumatera Selatan, Indonesia \\ ${ }^{2}$ Faculty of Agriculture, Muhamadiah University, Jalan Jenderal A. Yani 13 Ulu, Palembang 30263, Indonesia \\ ${ }^{3}$ Faculty of Agriculutre, Baturaja University, Jalan Ratu Penghulu, Baturaja 32113, Indonesia
}

Received October 21, 2008/Accepted December 8, 2009

\begin{abstract}
The flower characteristics of a plant is one of the important traits correlated to its productivity. Study on flower characteristics is useful to understand how to increase the crop productivity. The research was conducted at Agro Techno Park Center, Indonesian State Ministry of Research and Technology, Bakung Village, Ogan Ilir Distric South Sumatra from April 2007 to August 2008. The objective of this research was to evaluate the flower characteristics and the yield of jatropha (Jatropha curcas L.) accessions. The research was arranged in a randomized block design, consisted of fifteen accessions of jatropha, with three replicates. The Jatropha accessions were collected from different agro ecosystems located in Sumatra, Java, and Borneo. The results indicated that the evaluated accessions have significant differences in the flower characteristic and the yields. The ratio male-female flower is the most important character for $J$. curcas $L$. because it has a significant correlation to the yield.
\end{abstract}

Key words: flower, yield, Jatropha curcas

\section{INTRODUCTION}

The Jatropha development in Indonesia is still in controversial issues. The contra opinion argues that the Jatropha is not potential to be developed as a biofuel crop in Indonesia because of its low productivity. The maximum Jatropha productivity is only 5 tons of seeds per ha per year (Mahmud et al.2008) compared to palm oil which can produce 25 tons fresh fruit bunches per ha per year. Hence, we need to do some intensive researches for Jatropha development, for example how to increase its productivity. The Indonesian State Ministry of Research and Technology (2006) reported that one of problems for Jatropha development is the lack of superior varieties with high productivity and oil content.

In some crops, the superior varieties can be created by breeding program such as selection, introduction and crossing. The first step for creating a new variety is development of germplasm collection. Some researchers have reported the genetic variability of Jatropha (Heller et al. 1996; Yunus 2007; Sunil et al. 2009). Heller et al. (1996) have identified 13 accessions which have high potency of productivity. Those accessions were selected from some countries such as Senegal, Cape Verde, Ghana, Benin, Burma, India, Costa Rica, and Mexico. On the other hand, Indonesian Plantation Research Center reported that they have some varieties which were selected from different areas in Indonesia (Hasnam \& Mahmud 2006). The richness of Jatropha germplasm is a high potency as breeding materials for creating a Jatropha superior hybrid.

\footnotetext{
${ }^{*}$ Corresponding author. Phone: $+62-711-580461$, Fax: +62-711-580461, E-mail: andiswijaya@yahoo.com
}

The local germplasm are often used as important breeding materials. Granado et al. (2001) argued that the local germplasm as parental material in breeding program for many crops is optimal step for overcoming the marginal environment. The local germplasms have a high adaptation to marginal environment but they do not produce high yield even whey they are grown under optimal environment. There are some Jatropha local germplasms which are grown in Indonesia. Heller et al. (1996) informed that in 15 centuries the Portuguese distributed the Jatropha to African and Asian continents. However, the local germplasm has generally a low productivity. Therefore, it is needed to introduce new varieties as gene donor for increasing the productivity trait.

The flowering characteristic is the important trait which has a significant correlation to productivity. Miftahorrachman et al. (2000) argued that spiklet (female flower) of coconut has a high correlation to productivity. Liu et al. (2008) reported that the sex ratio of Sagittaria potamogefilia (female to male flower) decreased with the inflorescane numbers and the plant size, eventhough the nutrient had impact on the flower number and production. On the other hand, Mendez and Traveset (2003) reported that the plant can modify its gender through number of male and female flowers, stamens and carpels per flower or pollen grains and ovules per floral organ. Based on the above information, it is evidence that flower characters have a correlation to the yield. Because of that it is needed to evaluate the number of male and female flower and its correlation to the yield of Jatropha accessions collected from different areas in Indonesia. This information is very important to identify the Jatropha accessions and to understand how to increase the yield of Jatropha by modification of flower characters. 


\section{MATERIALS AND METHODS}

Germplasm Collection. The Jatropha accessions were from some different agro ecosystems. Criteria for mother trees: (i) the trees had to be old enough, indicated by the high of plant diameter; (ii) the trees were propagated from plant grow in those area; and (iii) the trees must be free from pest and diseases. The evaluated accessions in this research are described in Table 1.

Time and Location. The research was carried out from April 2007 to August 2008 at Agro Techno Park, Indonesian State Ministry Research and Technology. The research location was in Bakung village which is about $45 \mathrm{~km}$ from Palembang South Sumatra. It is classified as a wet tropical climate area with the average of more than 2,500 $\mathrm{mm}$ rain falls per year. Its temperature was range between $25-32^{\circ} \mathrm{C}$, the soil texture is sandy loam with low to middle soil property status.

Experimental Design. This research used Randomized Block Design with three replicates. Each treatment unit was $7.5 \times 6 \mathrm{~m}=45 \mathrm{~m}^{2}$. There was $4,000 \mathrm{~m}^{2}$ land for 15 accessions and each accession has 20 plant samples. The plants were 6 months old.

Parameters. The accession identification used the morphology and growth parameters. The parameters were: (i) Number of male flowers per inflorescence, (ii) Number of female flowers per inflorescence, (iii) Total flowers per inflorescence, (iv) Ratio male - female flowers per inflorescence, (v) Number of fruits per inflorescence, (vi) Seed weight per plant, (vii) Jatropha oil yield per plant.

Data Analysis. The quantitative data was analyzed by analysis of variance (ANOVA). The means values of the genotype were compared using Fischer's Least Significant Difference test (LSD test). The coefficient correlation between flower characteristics and yield was calculated using formula:

$$
r=\frac{\sum(X-\bar{X})(Y-\bar{Y})}{\sqrt{\sum(X-\bar{X})^{2}(Y-\bar{Y})^{2}}}
$$

Table 1. The evaluated accessions are collected

\begin{tabular}{|c|c|c|}
\hline Name of accession & Code accession & Note \\
\hline Komering & KMR & $\begin{array}{l}\text { Low land in Komering River } \\
\text { Catch Area }\end{array}$ \\
\hline Palembang & PLG & Low land Palembang \\
\hline Jogyakarta & JGY & Costal area in Jogyakarta \\
\hline Indralaya & INR & Swamp area in South Sumatra \\
\hline ATP 1 & ATP1 & $\begin{array}{l}\text { The best clone is selected from } \\
90 \text { clones which produced by } \\
\text { mutation from BATAN }\end{array}$ \\
\hline ATP 2 & ATP2 & $\begin{array}{l}\text { The second of the best clone is } \\
\text { selected from } 90 \text { clones which } \\
\text { produced by mutation from } \\
\text { BATAN }\end{array}$ \\
\hline Pontianak & PNT & Low land in Borneo \\
\hline Lahat & LHT & Middle land in South Sumatra \\
\hline Pagaralam & PGR & High land in South Sumatra \\
\hline Curup & CRP & High land in Bengkulu \\
\hline Lampung & LMP & $\begin{array}{l}\text { Plantation Research Center in } \\
\text { Bogor }\end{array}$ \\
\hline Medan & MDN & Low land in Medan \\
\hline Aceh Besar & ABS & Midle Land in Aceh \\
\hline Pidie & PDI & Low land in Aceh \\
\hline Gorontalo & GRT & PT. Rajawali Nusantara 2. \\
\hline
\end{tabular}

\section{RESULTS}

Analysis of Variance showed that there were highly significant in the most of observed parameters except ratio male flower to female flower (Table 1). It proved that the Jatropha accessesions have different performance in flower characteristics (Table 2).

We recorded that the accessions from ATP2, ATP1, and Pidie had the highest number of female flower. On the other hand, accessions from Indralaya, Aceh Besar and Gorontalo had a lower number of female flower (from 3.5 to 4.2) comparing to the other accessions. The average of female flowers of evaluated Jatropha accessions was 5.2 flowers per inflorescence. The number of female flowers of some different Jatropha accessions is shown in Figure 1.

We recorded that most of the accession had a relative similar number of male flowers. However, the LSD analysis showed that the ATP1 and ATP2 had the highest male flower number (Figure 2). They were 119.64 and 111.06 male flowers

Table 2. F-value and mean value of each character

\begin{tabular}{llc}
\hline Character & F-value & Mean value \\
\hline Number of female flower & $2.5291 * *$ & $5.20 \pm 1.09$ \\
Number of male flower & $3.2743^{* *}$ & $68.20 \pm 19.55$ \\
Total flower & $3,3200^{* *}$ & $74.20 \pm 20.38$ \\
Ratio male - female flower & $1.4540^{\mathrm{ns}}$ & $13.34 \pm 2.30$ \\
Fruit number & $2.1788^{*}$ & $5.40 \pm 0.19$ \\
Seed weight per plant (g/plant) & $351.61 * *$ & $149.20 \pm 103.47$ \\
Oil yield per plant (g/plant) & $3.9509 * *$ & $102.37 \pm 30.57$ \\
\hline
\end{tabular}

NS = Non Significant $(\mathrm{P}>0.05)$, *significant $(0.01<\mathrm{P} \leq 0.05)$, ** highly significant difference $(\mathrm{p} \leq 0.01)$.

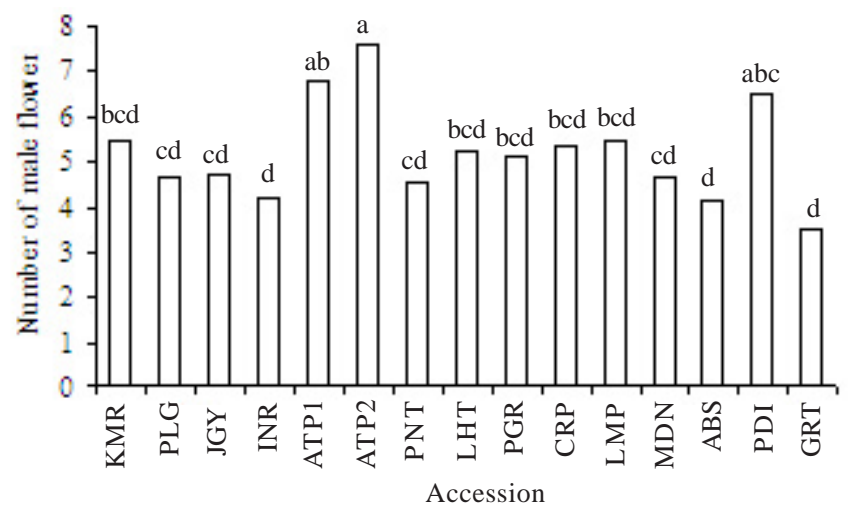

Figure 1. Number of female flower of some different Jatropha accessions.

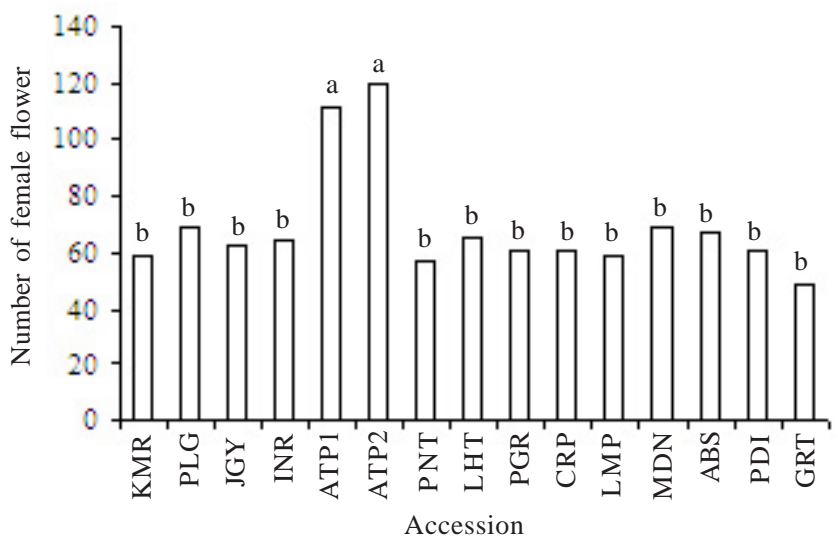

Figure 2. Number of male flower of some different Jatropha accessions. 
per inflorescence, whereas the average male flower was 68.20 male flowers per inflorescence respectively.

The analysis of variance of total flowers (female flowers and male flowers) showed that there was a significant difference among Jatropha accessions respectively. The LSD test showed that the ATP1 and ATP2 had the highest total flower number (Figure 3). They were 127.25 and 117.86 flowers per plant per inflorescence. The other accessions had a similar flower number with the average flower number was 74.20 flowers. On the other hand, there was no significant difference among the ratio of male and female flowers. The mean male female flower ratio of the observed accessions was 13.34 (Figure 4).

Fruit number per inflorescence showed the highest on the accessions from ATP2, ATP1, and Pidie. On the other hand, the accessions from Indralaya, Aceh Besar and Gorontalo had a lower number of fruit per inflorescence compared to the other accessions. The average of fruit number per inflorescence of evaluated Jatropha accessions was 5.4 fruits per inflorescence. The number of fruits per inflorescence of some different Jatropha accessions is shown in Figure 5.

The Analysis of Variance of seed weight per plant showed that the accessions can be divided into two groups. The first group belongs to the accessions from PDI, LMP, MDN, PLG, KMR, INR, LHT, PGR, and PNT. This group has a higher seed

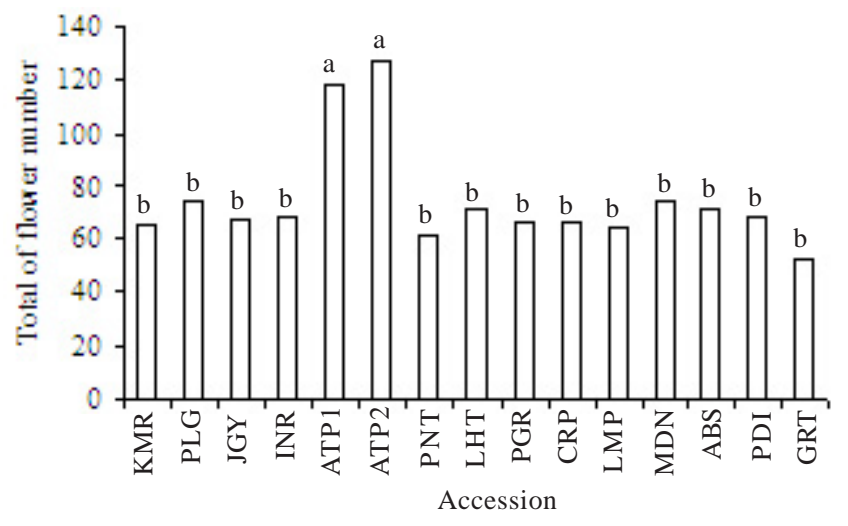

Figure 3. Total number of female flower of some different Jatropha accessions.

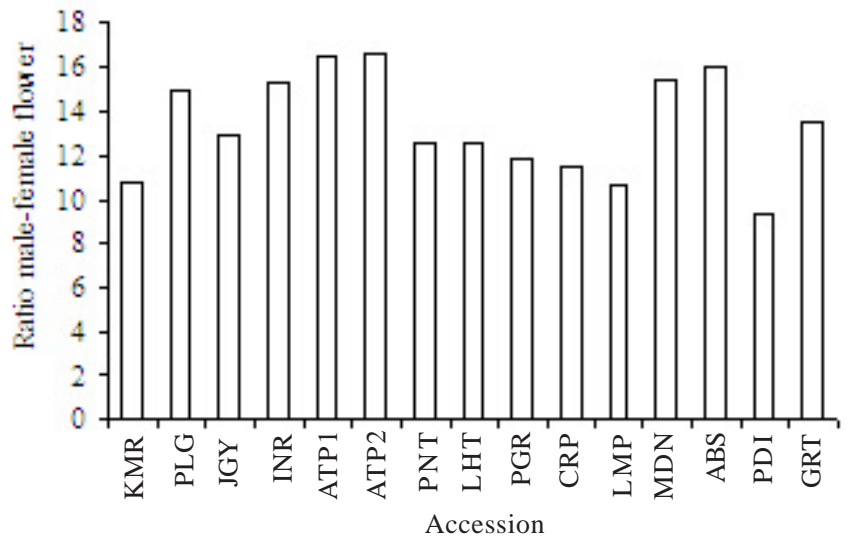

Figure 4. Ratio male-female flower of some different Jatropha accessions. weight per plant compared to the second group (Figure 6). The second group belongs to the accessions from ATP2, ATP1, CRP, ABS, JGY, and GRT. On the other hand, analysis of variance of oil yield per plant showed that the accessions produced a high variance of oil yield per plant (Figure 7). The highest oil yield per plant was produced by accession from LMP and PDI while the lowest oil yield per plant was produced by accession from GRT.

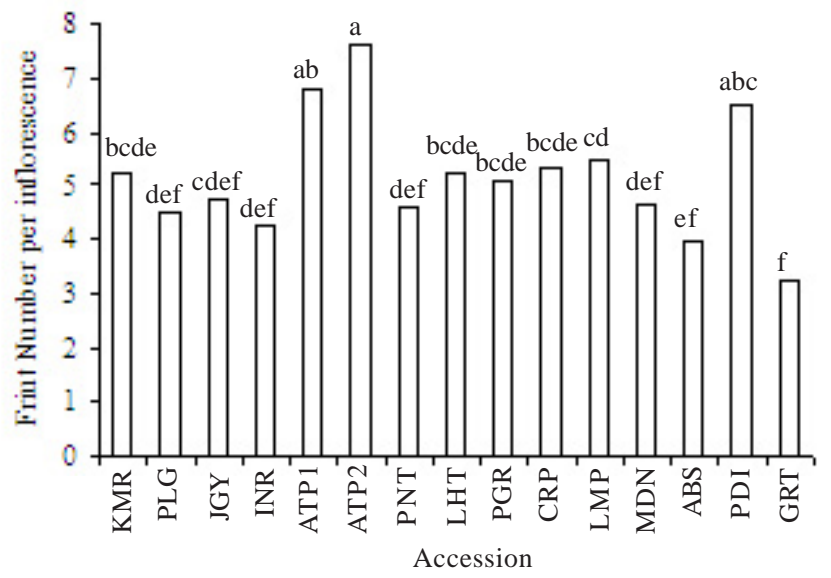

Figure 5. Fruit number per inflorescence of some Jatropha accessions.

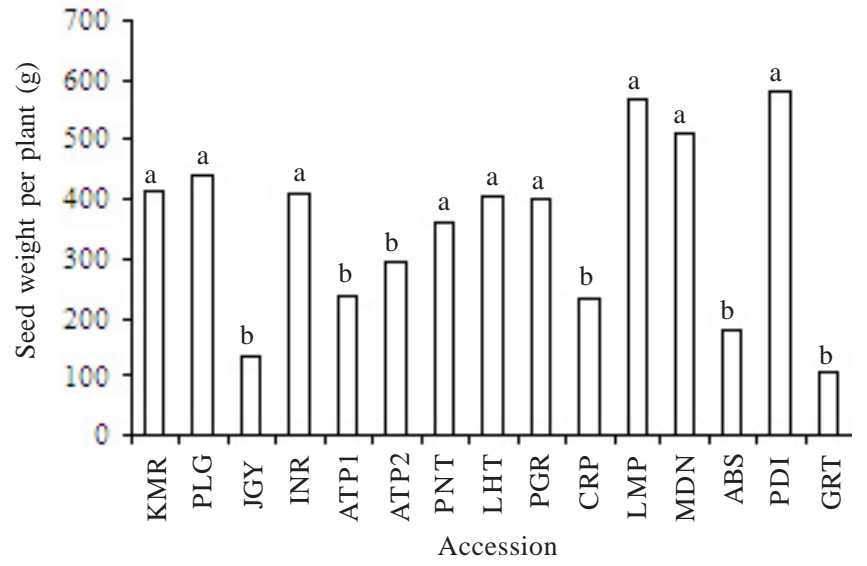

Figure 6. Seed weight per plant of some different Jatropha accessions.

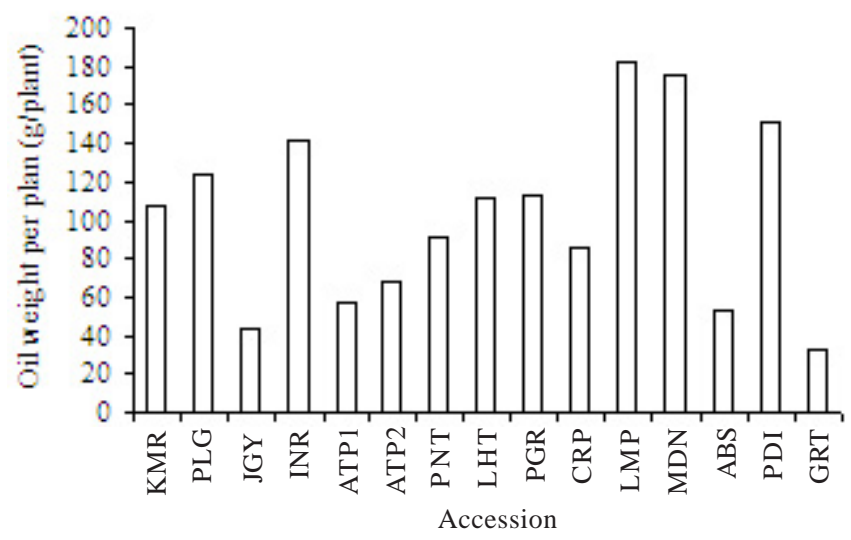

Figure 7. Oil yield per plant of some Jatropha accessions. 


\section{DISCUSSION}

We assumed that the highly significant differences in flower characters and yield among the accessions are due to the difference in agro ecosystem and location of seed source. Pupilli (2000) argued that an accession adapted for a long period of time in certain environment showed a special expression in its morphology characters. Therefore, the accessions from various agro ecosystems express various performances.

The average female flower of the evaluated Jatropha accessions was 5.2 female flowers per inflorescence. This number is similar to the result of Raju and Ezradanam (2003). They reported that the female flower number is 5 flowers per inflorescence.

This study showed that the Jatropha accessions have a high number of male flowers. On the other hand, the female flowers are rare. Ferry (2006) argued that the low number of female flowers is one of factors causing the low productivity of Jatropha productivity. Our results showed that there is a positive correlation between the female flower number and the yield (seed weight and oil yield per plant), however the correlation is quite low since the coefficient correlation is not significant difference. The highest yield is produced by the accession Lampung and Pidie (Figure $6 \& 7$ ). Both accessions have a middle number of female flowers. On the other hand, there is a significant negative correlation between male-female flower ratio and yield (Table 3 ).

This fact demonstrated that there is an optimal number of male flowers of Jatropha. The abundance of male flower has a relatively negative effect on yield, especially when the number of male flower is not proportional to the number of female flower. This happen since the seed of Jatropha is developed from female flower and the pollen is from the other plant. Raju and Ezradanam (2003) reported that the Jatropha is cross pollinating plant. Moreover, the seed weight production has a high correlation to the production of oil per plant (Table 3). Singh et al. (2008) have modified male-female flower ratio using plant growth regulator application for increasing the oil yield of Salvia sclarea L. in conclusion, of this study indicated that: (i) the evaluated Jatropha accessions have significant

Table 3. Coefficient correlation between flowering characters and yield

\begin{tabular}{lc}
\hline Character & Coefficient correlation to yield (oil yield) \\
\hline Number of male flower & $-0.1373^{\mathrm{ns}}$ \\
Number of female flower & $0.2831^{\mathrm{ns}}$ \\
Total flower & $-0.1069^{\mathrm{ns}}$ \\
Ratio male - female flower & $-0.3880^{*}$ \\
Fruit number per inflorescence & $0.0888^{\mathrm{ns}}$ \\
Seed weight per plant & $0.9496^{*}$ \\
Oil yield per plant & $0.3349^{*}$ \\
\hline
\end{tabular}

NS = Non Significant, *significant difference. differences of the flower characters and yield; (ii) the ratio male - female flowers and seed weight per plant are the important character because they have a significant correlation to the yield.

\section{ACKNOWLEDGEMENT}

This work is a part of project which is founded by HIBAH BERSAING project Directorate General Higher Education Indonesia National Education Department.

\section{REFERENCES}

Ferry Y. 2006. Menghitung perkiraan produksi Jarak Pagar. Info Tek Jarak Pagar (Jatropha curcas L.). Pusat Penelitian dan Pengembangan Perkebunan, Badan Penelitian dan Pengembangan Pertanian. Vol.1 (2) Februari 2006.

Granado S, von Bothmer R, Ceccarelli S. 2001. Genetic diversity of barley: Use of locally adapted germplasm to enhance yield and yield stability of barley in dry areas. In: Cooper HD, Spillane C, Hodgkin T (eds). Broadening the Genetics Base of Crop Production. IPG/FAO. 351-371.

Hasnam, Mahmud Z. 2006. Perbenihan jarak pagar (Jatropha curcas L.). Bogor. Pusat Penelitian dan Pengembangan Perkebunan Badan Penelitian dan Pengembangan Pertanian Departemen Pertanian.

Heller J, Engels J, Hammer K. 1996. Promoting the conservation and use of underutilized neglecgted crops 1. Physic nut (Jatropha curcas L.). Rome: International Plant Genetic Resources Institute.

Kementerian Negara Riset dan Teknologi Republik Indonesia. 2006. Indonesia 2005 - 2025 Buku Putih Penelitian, Pengembangan dan Penerapan Ilmu Pengetahuan dan Teknologi Bidang Sumber Energi Baru dan Terbarukan untuk Mendukung Keamanan Ketersediaan Energi Tahun 2025.

Liu F, Yue XL, Chen JM, Fang QF. 2008. Gender modification in monocious sepecies Sagittaria potamogefolia. Plant Ecoll 199:217-223.

Mahmud Z, Allorerung D, Rivae AA. 2008. Teknik budidaya jarak pagar (Jatropha curcas L.). Bogor. Pusat Penelitian dan Pengembangan Perkebunan Badan Penelitian dan Pengembangan Pertanian Departemen Pertanian.

Mendez M, Traveset A. 2003. Sexual allocation in single-flower hermaphroditic individuals in relation to plan and flower size. Oecologia 137:69-75.

Miftahorrachman HF, Mangindaan, Novirianto H. 2000. Analisis lintas karakter vegetatif dan generatif kelapa dalam kupal terhadap jumlah bunga betina. Zuriat 11:39-52.

Pupilli F, Lamborda P, Scotti C, Arcioni S. 2000. RFLP analysis allows for identification of alfalfa ecotypes. Plant Breeding 119:271276.

Raju AJS, Ezradanam V. 2003. Pollination ecology and fruiting behavior in monoecious species, Jatropha curcas L. (Euphorbiaceae). Current Science 83:1395-1398.

Singh V, Ruchi S, Ramesh K, Singh B. 2008. Effects of growth regulator application on growth, flower, oil yield and quality of clary sage (Salvia sclarea L.). J Herbs, Speci Medic Plants 14:29-36.

Sunil N et al. 2009. Analysis of diversity and distribution of Jatropha curcas L. germplasm using geographic information system. Gene Resourc Crop Evol 56:115-119.

Yunus A. 2007. Indentifikasi keragaman genetik jarak pagar (Jatropha curcas L.) di Jawa Tengah berdasarkan penanda Isoenzym. Biodiversitas 80:249-252. 